
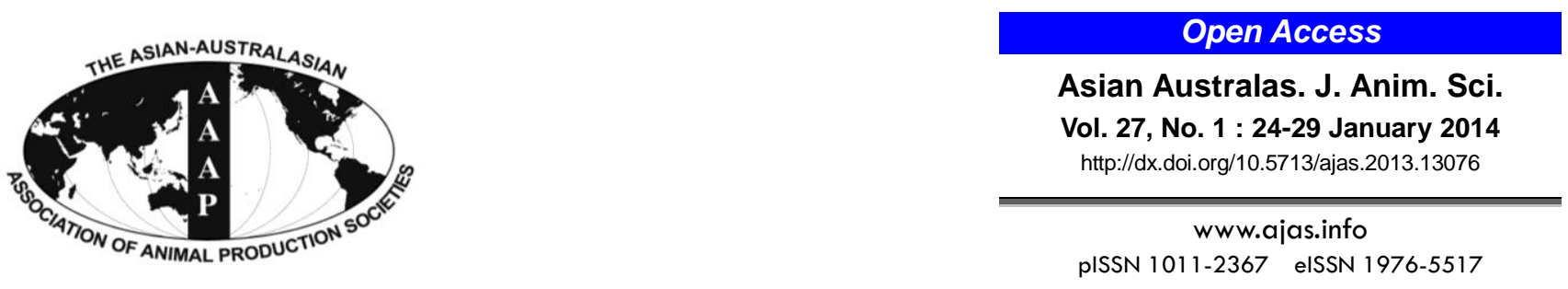

\title{
Ingestive Behavior and Nitrogen Balance of Confined Santa Ines Lambs Fed Diets Containing Soybean Hulls
}

\author{
Milena Patrícia Viana Bastos, Gleidson Giordano Pinto de Carvalho*, Aureliano José Vieira Pires, \\ Robério Rodrigues Silva, Antônio Eustáquio Filho ${ }^{1}$, Edileusa de Jesus dos Santos, \\ Daiane Maria Trindade Chagas, Daniele Soares Barroso, and George Abreu Filho \\ Southwest State University of Bahia, Itapetinga - Bahia, Brazil
}

\begin{abstract}
The objective of this study was to assess the effect of substituting corn with soybean hulls on the ingestive behavior and nitrogen balance of Santa Ines lambs. A total of 25 lambs with an initial body weight of $20 \pm 2 \mathrm{~kg}$ at approximately six months of age, sheltered individually in stalls $(1.10 \mathrm{~m} \times 1.0 \mathrm{~m})$, considering an entirely casual experimental delineation. Soybean hulls were substituted for corn at $0,250,500,750$, and $1,000 \mathrm{~g} / \mathrm{kg}$ of dry matter (DM). The time spent feeding, ruminating, masticating, and resting was not affected by the substitution of corn with soybean hulls. In fact, the feeding efficiency in $\mathrm{g} D \mathrm{D} / \mathrm{h}$ and the rumination efficiency in $\mathrm{g}$ $\mathrm{DM} /$ bolus increased linearly with soybean hull substitution in the feed. Although the nitrogen balance was not altered by the use of soybean hulls as a substitute for corn in the diets of Santa Ines lambs, the $\mathrm{N}$ ingested and $\mathrm{N}$ digested expressed in $\mathrm{g} / \mathrm{d}, \mathrm{N}$ retained as a percentage of that ingested, and $\mathrm{N}$ retained as a percentage of that digested displayed quadratic behavior. In conclusion, corn can be substituted with soybean hulls up to $1,000 \mathrm{~g} / \mathrm{kg}$ of dry matter in the concentrate, without changing the ingestive behavior and nitrogen balance. (Key Words: Alternative Feed, Meat Production, Nutrition, Sheep)
\end{abstract}

\section{INTRODUCTION}

Among the difficulties related to the production of lambs in tropical countries is the low quality of forages and their seasonal nature, which leads to an irregular production of forage over the course of a year. Due to the high cost concentrate food, agro-industrial coproducts are being targeted for studies on animal feed under both economic and nutritional perspectives.

Accordingly, efforts are being made to identify lower cost, alternative feeds that are capable of partially or fully substituting the concentrates (Carvalho et al., 2006; Rebouças, 2007; Carvalho et al., 2008).

Soybean hulls are an agro-industrial coproduct of soy

\footnotetext{
* Corresponding Author: G. G. P. Carvalho. Tel: +55-71-32836716, Fax: +55-71-3283-6718, E-mail: gleidsongiordano@ yahoo.com.br

${ }^{1}$ Federal University of Bahia, Salvador - Bahia, Brazil, CEP 40170-110

Submitted Jan. 26, 2013; Accepted Jun. 17, 2013; Revised Jul. 31, 2013
}

processing and are one such alternative. Indeed, studies have demonstrated that soybean can be considered an energy supplement because its inclusion in ruminant diets results in performance comparable to that of corn due to a high digestibility of the cell wall, which is essentially composed of cellulose.

Protein is one of the most expensive ingredients of ruminant diets, and feeding costs are highly dependent on the efficiency of use. The concentration of ammoniacal $\mathrm{N}$ in the rumen is critical to bacterial growth when it is associated with energy sources and is directly related to the solubility of dietary protein and the $\mathrm{N}$ retention by the animal. Therefore, it is necessary to adapt the ingestion of $\mathrm{N}$ and energy to optimize microbial protein synthesis and the reduction of excessive losses of $\mathrm{N}$ (NRC, 2001).

Confined ruminants are generally fed twice a day, being provided two main meals soon after the feed is offered, with one to three hour's duration, as well as variable intervals for short meals. However, feeding conditions and feed characteristics can alter the ingestive behavior parameters 
because interactions among the diet nutrients can increase microbial efficiency and improve digestibility, shortening rumen retention time.

The present work was performed with the objective of assessing the effect on ingestive behavior and nitrogen balance of different levels of soybean hulls as a substitute for corn in the diets of Santa Ines lambs.

\section{MATERIAL AND METHODS}

The experiment was conducted at the Animal Experimentation, Forage Crops and Pastures Laboratories of Universidade Estadual do Sudoeste da Bahia, ItapetingaBA campus, during the period June to October in 2009.

\section{Experimental design, animals, housing, and diets}

A total of 25 non-castrated male Santa Ines lambs were used; the animals were, on average, six months old and had an initial body weight of $20 \pm 2.0 \mathrm{~kg}$. The lambs were sheltered in individual bails $\left(1.10 \mathrm{~m}^{2}\right)$ provided with cement floors, feeders and waterers.

In the pre-experimental period, the bails were numbered, and the animals were earmarked and dewormed for ectoand endoparasites. The animals were randomly distributed in treatments consisting of diets with different levels of soybean hulls as a substitute for corn in the concentrate $(0$, $250,500,750$, and $1,000 \mathrm{~g} / \mathrm{kg}$ of dry matter), in accordance with an entirely causal experiment delineation.
Table 1. Chemical-bromatological composition of the ingredients of experimental diets on a dry matter basis

\begin{tabular}{lcrrr}
\hline \multirow{2}{*}{ Item } & \multicolumn{4}{c}{ Ingredient } \\
\cline { 2 - 5 } & $\begin{array}{c}\text { Elephant } \\
\text { grass silage }\end{array}$ & Corn & $\begin{array}{c}\text { Soybean } \\
\text { meal }\end{array}$ & $\begin{array}{c}\text { Soybean } \\
\text { hulls }\end{array}$ \\
\hline $\mathrm{DM}^{1}$ & 262.5 & 878.9 & 897.2 & 891.9 \\
$\mathrm{MO}^{2}$ & 913.2 & 982.1 & 932.6 & 966.1 \\
$\mathrm{CP}^{2}$ & 58.7 & 71.1 & 445.0 & 88.0 \\
$\mathrm{EE}^{2}$ & 25.0 & 20.5 & 16.8 & 21.3 \\
$\mathrm{MM}^{2}$ & 86.8 & 17.9 & 67.4 & 33.9 \\
$\mathrm{NDF}^{2}$ & 764.0 & 139.0 & 143.0 & 699.0 \\
$\mathrm{ADF}^{2}$ & 431.4 & 36.1 & 96.5 & 483.6 \\
$\mathrm{HEM}^{2}$ & 332.6 & 102.9 & 46.5 & 215.4 \\
$\mathrm{LIG}^{2}$ & 77.6 & 17.2 & 18.0 & 31.3 \\
\hline
\end{tabular}

${ }^{1} \mathrm{~g} / \mathrm{kg}$ of natural matter. ${ }^{2} \mathrm{~g} / \mathrm{kg}$ of dry matter.

The experiment lasted for $106 \mathrm{~d}$, with $14 \mathrm{~d}$ spent for adaptation to the premises, experimental diets and management and $92 \mathrm{~d}$ of assessment and data collection. During this period, intake adjustments were made by weighing the feed supplied and the surplus, allowing ingestion at will, with a surplus of $100 \mathrm{~g} / \mathrm{kg}$ of natural matter. The diets were formulated in accordance with the nutritional recommendations of NRC (2006), aiming at an average daily gain of $200 \mathrm{~g}$, and were isoproteic, with 160 to $187.0 \mathrm{~g} / \mathrm{kg}$ of crude protein on a dry matter basis (Table 2).

Elephant grass silage was used as the forage in a

Table 2. Ingredient and chemical-bromatological $(\mathrm{g} / \mathrm{kg})$ composition of experimental diets

\begin{tabular}{|c|c|c|c|c|c|}
\hline \multirow{2}{*}{ Composition } & \multicolumn{5}{|c|}{ Level of soybean hulls ${ }^{3}$} \\
\hline & 0 & 250 & 500 & 750 & 1,000 \\
\hline Corn $^{1}$ & 208.0 & 156.0 & 104.0 & 52.0 & 0.00 \\
\hline Soybean meal ${ }^{1}$ & 171.6 & 171.2 & 172.0 & 172.8 & 173.2 \\
\hline Soybean hull ${ }^{1}$ & 0.00 & 52.0 & 104.0 & 156.0 & 208.0 \\
\hline Urea $^{1}$ & 24.0 & 22.0 & 20.0 & 18.0 & 17.0 \\
\hline Mineral mixture ${ }^{1,4}$ & 30.0 & 30.0 & 30.0 & 30.0 & 30.0 \\
\hline Elephant grass silage $^{1}$ & 600.0 & 600.0 & 600.0 & 600.0 & 600.0 \\
\hline Total & $1,000.0$ & $1,000.0$ & $1,000.0$ & $1,000.0$ & $1,000.0$ \\
\hline \multicolumn{6}{|c|}{ Chemical-bromatological } \\
\hline $\mathrm{DM}^{2}$ & 508.0 & 509.0 & 509.0 & 513.0 & 512.0 \\
\hline $\mathrm{OM}^{2}$ & 930.0 & 925.0 & 925.0 & 924.0 & 923.0 \\
\hline $\mathrm{CP}^{2}$ & 185.0 & 170.0 & 160.0 & 187.0 & 176.0 \\
\hline $\mathrm{EE}^{2}$ & 28.0 & 30.0 & 28.0 & 29.0 & 26.0 \\
\hline $\mathrm{MM}^{2}$ & 70.0 & 75.0 & 75.0 & 76.0 & 77.0 \\
\hline $\mathrm{NDF}^{2}$ & 516.0 & 534.0 & 536.0 & 554.0 & 575.0 \\
\hline $\mathrm{ADF}^{2}$ & 273.0 & 273.0 & 273.0 & 274.0 & 273.0 \\
\hline $\mathrm{NDF}_{\mathrm{AP}}^{2}$ & 388.0 & 391.0 & 392.0 & 389.0 & 386.0 \\
\hline $\mathrm{TC}^{2}$ & 717.0 & 724.0 & 737.0 & 708.0 & 721.0 \\
\hline $\mathrm{NFC}^{2}$ & 250.0 & 234.0 & 257.0 & 218.0 & 225.0 \\
\hline $\mathrm{TDN}^{2}$ & 823.0 & 792.0 & 771.0 & 782.0 & 784.0 \\
\hline
\end{tabular}

${ }^{1} \mathrm{~g} / \mathrm{kg}$ natural matter. ${ }^{2} \mathrm{~g} / \mathrm{kg}$ of dry matter.

${ }^{3}$ Level of corn replaced with soybean hulls in the concentrate.

${ }^{4}$ Levels of assurance (nutrients/kg): calcium, $170 \mathrm{~g}$; sulfur, $19 \mathrm{~g}$; phosphorus, $85 \mathrm{~g}$; magnesium, $13 \mathrm{~g}$; sodium, $113 \mathrm{~g}$; copper, $600 \mathrm{mg}$; cobalt, $45 \mathrm{mg}$; chrome, $20 \mathrm{mg}$; iron, 1,850 mg; maximum fluorine, $850 \mathrm{mg}$; iodine, $80 \mathrm{mg}$; manganese, 1,350 mg; selenium, $16 \mathrm{mg}$; zinc, 4,000 mg. 
forage:concentrate ratio of $600 \mathrm{~g} / \mathrm{kg}$ forage to $400 \mathrm{~g} / \mathrm{kg}$ concentrate. The concentrates were composed of corn, soybean meal, urea, a mineral mixture, and soybean hulls. The chemical composition of the ingredients are given in Table 1, and the percent and chemical composition of the ingredients of the experimental diets are given in Table 2.

The diets were offered twice a day at 6 am and $3 \mathrm{pm}$ in the form of complete feed (silage+concentrate). Water was available to the animals ad libitum and supplied in plastic buckets.

During the experimental phase, the concentrate was sampled weekly; the surplus and silage samples were collected daily, forming composite samples every $21 \mathrm{~d}$ per period, per animal and per treatment and placed in plastic bags and stored in a freezer $\left(-10^{\circ} \mathrm{C}\right.$ to $\left.-5^{\circ} \mathrm{C}\right)$.

At the end of the experiment, the samples were defrosted at room temperature for $4 \mathrm{~h}$ and pre-dried in a forced-air circulation oven at $55^{\circ} \mathrm{C}$ for $72 \mathrm{~h}$. The samples were then processed using a Willey cutting mill with a 1 $\mathrm{mm}$ sieve. The levels of dry matter (DM), crude protein $(\mathrm{CP})$, ether extract (EE) and mineral matter (MM) were estimated according to the recommendations of the Association of Official Agricultural Chemists (AOAC, 1990), as described by Silva and Queiroz (2002). The neutral detergent fiber (NDF), acid detergent fiber (ADF), hemicellulose (HEM) and lignin $\left(\mathrm{H}_{2} \mathrm{SO}_{4} 72 \%\right)$ contents were measured according to the methodology described by Van Soest et al. (1991). The organic matter (OM) was obtained using the following formula: OM $(\mathrm{g} / \mathrm{kg} \mathrm{DM})=100-\mathrm{MM}$ (g/kg DM).

\section{Sampling and measurements}

Behavioral observations were conducted on the 53rd and 92nd days of the second and fourth experimental periods, respectively, by means of visual observations at five-minute intervals, using the methodology proposed by Carvalho et al. (2007), for a period of $24 \mathrm{~h}$. The time spent feeding, ruminating, and resting was recorded on previously prepared forms. On the days that followed, observations of each animal were performed at three time points during the day: morning, afternoon, and evening; the number of mastications per ruminal bolus and the time spent ruminating each bolus were recorded.

The data collection to ascertain the time spent on each activity was performed with the use of digital chronometers handled by four observers who were situated so as not to disturb the animals. Illumination was used in the evening. This procedure was initiated two days before beginning the ingestive behavior assessment so that the animals could adapt to this condition (Burger et al., 2000).

The voluntary intake of DM and NDF on the 53rd and 92nd days was considered for assessment of the feeding and rumination efficiency in min/g DM and NDF, g DM and
$\mathrm{NDF} / \mathrm{h}, \mathrm{g}$ of DM and NDF/bolus and $\mathrm{g} \mathrm{DM}$ and NDF/h, and average intake of DM and NDF per feeding period.

The number of boli ruminated daily was obtained by dividing the total ruminating time $(\mathrm{min})$ by the average time spent ruminating one bolus. The concentrations of DM and NDF in each ruminated bolus ( $g$ ) were obtained by dividing the quantity of DM and NDF consumed (g/d) in $24 \mathrm{~h}$ by the number of boli ruminated daily. The feeding and rumination efficiencies, expressed in $\mathrm{g} \mathrm{DM} / \mathrm{h}$ and $\mathrm{g} \mathrm{NDF} / \mathrm{h}$, were obtained by dividing the average daily intake of DM and NDF by the total time spent feeding and/or ruminating in 24 $\mathrm{h}$, respectively.

Urine was collected using the "spot" method. During the collection period, "spot" (single collection) samples of urine from each animal were obtained during spontaneous urination on the 39th $\mathrm{d}$ of the second experimental period at approximately four hours after the morning food offering.

Immediately after collection, urine samples were filtered through gauze, and a $10 \mathrm{~mL}$ aliquot of urine was diluted in $40 \mathrm{~mL}$ sulfuric acid to $0.036 \mathrm{~N}$. The $\mathrm{pH}$ was subsequently measured and, when necessary, adjusted to values under three with small drops of concentrated sulfuric acid to avoid bacterial destruction of the purine derivatives or precipitation of sulfuric acid. The samples were stored at $-20^{\circ} \mathrm{C}$ for later analysis.

The estimated daily volume of urine was calculated by multiplying the average creatinine excreted by the average body weight of each lamb and dividing it by the concentration of creatinine $(\mathrm{mg} / \mathrm{L})$ in the spot sample. With the volume of urine and the level of $\mathrm{N}$ in urine, the $\mathrm{N}$ excreted was calculated in $\mathrm{g} / \mathrm{d}$. The total level of nitrogen in urine was measured with the Kjeldahl method, following the procedures described by Silva and Queiroz (2002); the nitrogen balance was calculated using the formula: $\mathrm{BN}$ or $\mathrm{N}_{\text {retained }}=\mathrm{N}_{\text {intake }}-\left(\mathrm{N}_{\text {feces }}+\mathrm{N}_{\text {urine }}\right)$.

\section{Statistical analyses}

Statistical analyses of the data were carried out with a program called SAEG (Statistic and Genetic Assessment System) (Ribeiro Junior, 2001), with a 5\% significance level.

\section{RESULTS AND DISCUSSION}

The level of inclusion of soybean hulls as a substitute for corn did not provoke any changes $(p>0.05)$ in the ingestive behavior of the animals (Table 2).

Because there was no variation in intake of DM or NDF, no differences were observed for the variable intake related to ingestive behavior. Certainly the NDF content increased in the diets was not sufficient to limit intake. The intake of DM data relate to the days when the ingestive behavior was assessed (Table 3). 
Table 3. Intake of dry matter (CDM) and neutral detergent fiber (CNDF) in $24 \mathrm{~h}$ and time spent feeding, ruminating, masticating, and resting by lambs fed diets containing different levels of soybean hulls as a substitute for corn

\begin{tabular}{|c|c|c|c|c|c|c|c|c|c|}
\hline \multirow{2}{*}{ Item } & \multicolumn{5}{|c|}{ Level of soybean hulls } & \multirow{2}{*}{ SE** } & \multicolumn{3}{|c|}{ p-value } \\
\hline & 0 & 250 & 500 & 750 & 1,000 & & $\mathrm{~L}$ & Q & $\mathrm{C}$ \\
\hline \multicolumn{10}{|l|}{ Intake } \\
\hline $\mathrm{CDM}(\mathrm{min} / \mathrm{d})$ & 603.5 & 643.1 & 705.1 & 637.2 & 763.0 & 22.0 & $0.057^{1}$ & 0.819 & 0.283 \\
\hline $\mathrm{CNDF}(\mathrm{min} / \mathrm{d})$ & 214.4 & 253.0 & 283.4 & 244.2 & 298.0 & 27.1 & $0.126^{2}$ & 0.742 & 0.319 \\
\hline \multicolumn{10}{|l|}{ Feeding } \\
\hline $\mathrm{Min} / \mathrm{d}$ & 275.0 & 284.5 & 301.5 & 279.0 & 273.5 & 11.6 & $0.855^{3}$ & 0.220 & 0.840 \\
\hline Min/kg DM & 471.8 & 441.6 & 432.9 & 441.6 & 368.7 & 17.8 & $0.072^{4}$ & 0.602 & 0.353 \\
\hline $\mathrm{Min} / \mathrm{kg}$ NDF & $1,517.3$ & $1,150.7$ & $1,104.2$ & $1,219.4$ & 965.1 & 36.1 & $0.090^{5}$ & 0.331 & 0.417 \\
\hline \multicolumn{10}{|l|}{ Rumination } \\
\hline $\operatorname{Min} / \mathrm{d}$ & 556.5 & 603.0 & 520.5 & 570.5 & 568.0 & 9.6 & $0.904^{6}$ & 0.708 & 0.331 \\
\hline Min/kg DM & 958.3 & 944.3 & 745.6 & 897.7 & 761.8 & 15.9 & $0.034^{7}$ & 0.646 & 0.601 \\
\hline Min/kg NDF & $3,072.2$ & $2,465.0$ & $1,913.1$ & $2,435.1$ & $2,006.1$ & 36.1 & $0.090^{8}$ & 0.331 & 0.417 \\
\hline \multicolumn{10}{|l|}{ Mastication } \\
\hline No/bolus & 62.1 & 65.1 & 63.3 & 67.8 & 69.7 & 13.7 & $0.174^{9}$ & 0.777 & 0.871 \\
\hline Sec/bolus & 45.4 & 48.5 & 45.1 & 48.5 & 47.6 & 11.2 & $0.563^{10}$ & 0.901 & 0.777 \\
\hline $\operatorname{Min} / \mathrm{d}$ & 831.5 & 887.5 & 822.0 & 849.5 & 841.5 & 8.2 & $0.858^{11}$ & 0.767 & 0.395 \\
\hline Min/kg DM & $1,430.1$ & $1,385.9$ & $1,178.5$ & $1,339.3$ & $1,130.6$ & 15.2 & $0.031^{12}$ & 0.907 & 0.467 \\
\hline Min/kg NDF & $4,589.5$ & $3,615.7$ & $3,017.3$ & $3,654.5$ & $2,971.2$ & 36.4 & $0.097^{13}$ & 0.413 & 0.367 \\
\hline \multicolumn{10}{|l|}{ Resting } \\
\hline $\mathrm{Min} / \mathrm{d}$ & 608.5 & 552.5 & 618.0 & 590.5 & 598.5 & 11.8 & $0.857^{14}$ & 0.767 & 0.394 \\
\hline
\end{tabular}

A number of factors may compromise the ingestion of food, causing a direct effect on ingestive behavior, such as the level of NDF and the physical form of the diet; according to Van Soest (1994), these are the main factors that may affect rumination time.

In the present work, the experimental diets had the same particle size because only one type of forage was used in a constant forage:concentrate proportion, which may explain the absence of any significant effects on rumination activity. The only difference was with regard to the level of soybean hull substitution.

Changes would have been expected in the animals' ingestive behavior with the substitution of an ingredient containing a low level of NDF (corn) with a non-forage fiber source (soybean hulls) (Mertens, 1997).

However, according to Armentano and Pereira (1997) and Van Soest (1994), the total mastication time is more strongly influenced by the forage content and size of particles in the feed. By relating this information to the results obtained in the present work, we estimate that the lack of effect on mastication resulted from the similar particle size in the experimental diets because the same proportion of concentrate was offered in all the diets.

The feeding, rumination, mastication, and resting time values $(\mathrm{min} / \mathrm{d})$ did not reflect any significant effect of the diets with regard to feeding, ruminating, masticating, and resting activities (Table 3).

The lack of a significant effect $(\mathrm{p}>0.05)$ for mastication activities in No/bolus, sec/bolus, No/d and $\mathrm{min} / \mathrm{d}$ may be related to the similarity of the particle sizes because the process adopted was the same for all the diets.

The feeding efficiency expressed in $\mathrm{g} D M / h$ increased linearly $(p<0.05)$ with the substitution of soybean hulls in the diet.

However, the same was not observed for the intake of $\mathrm{DM}$, which did not display any significant effect $(\mathrm{p}>0.05)$ with the increasing level of soybean hulls as a substitute for corn. This feeding efficiency variable generally suffers due to the influence of DM intake. In any case, the higher level of NDF in the soybean hulls in relation to corn may have lowered the energy density of the soybean hull diets, which appears to have contributed to increase both the feeding efficiency $(\mathrm{g} / \mathrm{DM} / \mathrm{h})$ and rumination efficiency $(\mathrm{g}$ DM/bolus).

For the variable feeding efficiency expressed in $g$ $\mathrm{NDF} / \mathrm{h}$, no influence of the diets was observed $(\mathrm{p}>0.05)$ with the elevation of the soybean hull level. This absence of an effect may be explained by the similar intake of NDF observed (Table 4). This result allows us to state that this research the particle size was more important than the NDF content of the diet.

The rumination efficiency expressed in bolus $(\mathrm{n} / \mathrm{d}), \mathrm{g}$ 
Table 4. Food and rumination efficiency (g DM and NDF/h) of lambs fed diets containing different levels of soybean hulls as a substitute for corn

\begin{tabular}{|c|c|c|c|c|c|c|c|c|c|}
\hline \multirow{2}{*}{ Item } & \multicolumn{5}{|c|}{ Level of soybean hulls } & \multirow{2}{*}{ SE* } & \multicolumn{3}{|c|}{ p-value } \\
\hline & 0 & 250 & 500 & 750 & 1,000 & & $\mathrm{~L}$ & $\mathrm{Q}$ & $\mathrm{C}$ \\
\hline \multicolumn{10}{|l|}{ Food efficiency } \\
\hline $\mathrm{g} \mathrm{DM} / \mathrm{h}$ & 132.5 & 137.3 & 140.5 & 138.9 & 166.3 & 4.49 & $0.042^{1}$ & 0.293 & 0.347 \\
\hline $\mathrm{g} \mathrm{NDF} / \mathrm{h}$ & 23.5 & 25.0 & 32.6 & 25.6 & 31.4 & 1.43 & $0.119^{2}$ & 0.619 & 0.516 \\
\hline \multicolumn{10}{|c|}{ Rumination efficiency } \\
\hline Bolus (No/d) & 738.5 & 746.6 & 704.0 & 714.8 & 718.2 & 18.11 & $0.578^{3}$ & 0.775 & 0.739 \\
\hline g DM/bolus & 0.82 & 0.86 & 1.02 & 0.91 & 1.06 & 0.032 & $0.031^{4}$ & 0.875 & 0.548 \\
\hline g NDF/bolus & 0.29 & 0.34 & 0.41 & 0.34 & 0.41 & 0.019 & $0.072^{5}$ & 0.586 & 0.418 \\
\hline $\mathrm{g} \mathrm{DM} / \mathrm{h}$ & 65.8 & 63.9 & 81.4 & 67.4 & 80.3 & 2.152 & $0.048^{6}$ & 0.925 & 0.625 \\
\hline $\mathrm{g} \mathrm{NDF} / \mathrm{h}$ & 23.5 & 25.0 & 32.6 & 25.6 & 31.4 & 1.432 & $0.119^{7}$ & 0.619 & 0.516 \\
\hline
\end{tabular}

* SE $=$ Standard error of the mean.

${ }^{1} \hat{Y}=129.280+0.276330 \mathrm{X} .{ }^{2} \hat{Y}=25.8 .{ }^{3} \hat{Y}=724.4 .{ }^{4} \hat{Y}=0.827625+0.00213473 \mathrm{X} .{ }^{5} \hat{Y}=0.36 .{ }^{6} \hat{Y}=71.7 .{ }^{7} \hat{Y}=27.6$.

$\mathrm{NDF} / \mathrm{bolus}, \mathrm{g} \mathrm{DM} / \mathrm{h}$, and $\mathrm{g} \mathrm{NDF} / \mathrm{h}$ was not affected by replacing corn with soybean hulls (Table 4). Therefore, the contribution of the DM and NDF fractions in the ruminated boli may have originated from the forage, which was the same in all the diets and soybean hulls.

The rumination efficiency expressed in $\mathrm{g} \mathrm{DM} / \mathrm{bolus}$ increased linearly $(\mathrm{p}<0.05)$ based on the increase in the quantity of soybean hulls in the diet. The similarity of time spent ruminating may be explained by the similarity in the fiber's physical form because rumination time is influenced by the nature of the diet and is proportional to the level of cell wall in the feed (Van Soest, 1994).

The nitrogen ingested (N-ING) expressed in $\mathrm{g} / \mathrm{d}$ displayed a quadratic effect $(\mathrm{p}<0.05)$ with the soybean hull substitution (Table 5). Minimum ingestion was obtained in the feeds containing $36.97 \%$ soybean hulls as substitute for corn, resulting in $19.67 \mathrm{~g}$ of nitrogen.

Increased $\mathrm{N}$ ingestion is associated with a higher production of urea in the liver and higher excretion of urea in urine; in contrast, to maintain the plasmatic urea pool, which is under homeostatic physiological control, low $\mathrm{N}$ ingestion leads to reduced excretion of urea in the urine
(Van Soest, 1994).

No differences resulting from the level of soybean hulls as a substitute for corn were observed for the excretion of nitrogen through feces ( $p>0.05$ ), with an average of $6.2 \mathrm{~g} / \mathrm{d}$. The literature indicates that the main factor affecting the loss of $\mathrm{N}$ via feces is the forage:concentrate ratio because a higher level of concentrate in the diet results in a higher rate of passage and, consequently, increased $\mathrm{N}$ loss through microbial activity. Accordingly, the absence of any significant effect for $\mathrm{N}$-feces may be explained by the $\mathrm{F}: \mathrm{C}$ ratio being the same (60:40) in the treatments. This absence of effect is also due to the fact of the experimental diets were isonitrogenous.

A result similar to that observed in the present study was reported by Gentil (2010), who used young Santa Ines lambs to assess the $\mathrm{N}$ balance with the partial substitution of corn for soybean hulls at $(0,20,40$, and $60 \%)$. This author did not observe any effects on fecal nitrogen with soybean hull substitution; however, the average value (9.49 $\mathrm{g} / \mathrm{d}$ ) was higher than that in the present study.

The $\mathrm{N}$ digested (expressed in $\mathrm{g} / \mathrm{d}$ ) displayed a quadratic effect with the soybean hull substitution in the feed: a

Table 5. Ingestion of nitrogen (N-ING), excretion of nitrogen in feces ( $\mathrm{N}$-feces), digested or absorbed nitrogen (N-DIG) and retained nitrogen (N-retained) in lambs fed diets containing different levels of soybean hulls as a substitute for corn

\begin{tabular}{|c|c|c|c|c|c|c|c|c|c|}
\hline \multirow{2}{*}{ Item } & \multicolumn{5}{|c|}{ Level of soybean hulls } & \multirow{2}{*}{$\mathrm{SE}^{*}$} & \multicolumn{3}{|c|}{ p-value } \\
\hline & 0 & 250 & 500 & 750 & 1,000 & & $\mathrm{~L}$ & Q & $\mathrm{C}$ \\
\hline$\overline{N-I N G ~(g / d)}$ & 22.9 & 21.8 & 19.5 & 25.0 & 25.0 & 0.439 & 0.042 & $0.013^{1}$ & 0.198 \\
\hline $\mathrm{N}$-feces $(\mathrm{g} / \mathrm{d})$ & 6.1 & 6.0 & 6.5 & 6.0 & 6.3 & 0.041 & $0.305^{2}$ & 0.421 & 0.360 \\
\hline N-DIG (g/d) & 16.8 & 15.8 & 12.9 & 19.0 & 18.7 & 0.441 & 0.053 & $0.011^{3}$ & 0.174 \\
\hline N-DIG (\% ING) & 73.2 & 72.0 & 66.4 & 76.1 & 74.6 & 3.900 & 0.133 & $0.004^{4}$ & 0.122 \\
\hline $\mathrm{N}$-urine $(\mathrm{g} / \mathrm{d})^{* *}$ & 0.69 & 0.77 & 0.45 & 0.58 & 2.93 & 0.107 & 0.001 & $0.001^{5}$ & $0.001^{5}$ \\
\hline N-retained (\% ING) & 70.1 & 68.5 & 64.1 & 73.8 & 62.7 & 5.900 & 0.194 & $0.006^{6}$ & 0.638 \\
\hline N-retained (\% DIG) & 95.7 & 95.0 & 96.5 & 96.4 & 84.0 & 3.400 & 0.006 & $0.002^{7}$ & 0.003 \\
\hline N Balance & 16.1 & 15.1 & 12.5 & 18.5 & 15.8 & 0.471 & $0.418^{8}$ & 0.169 & 0.049 \\
\hline
\end{tabular}

$* \mathrm{SE}=$ Standard error of the mean. $* * \mathrm{p}<0.001$.

${ }^{1} \hat{Y}=22.8267-0.0876830 \mathrm{X}+0.00118574 \mathrm{X}^{2} .{ }^{2} \hat{Y}=6.2 .{ }^{3} \hat{Y}=16.7577-0.0922800 \mathrm{X}+0.00121954 \mathrm{X}^{2} .{ }^{4} \hat{Y}=72.5$.

${ }^{5} \hat{Y}=0.931967-0.0388502 \mathrm{X}+0.000555111 \mathrm{X}^{2} .{ }^{6} \hat{Y}=69.1387+0.00523624 \mathrm{X}-0.000383570 \mathrm{X}^{2} .{ }^{7} \hat{Y}=94.3293+0.199665 \mathrm{X}-0.00282689 \mathrm{X}^{2} .{ }^{8} \hat{Y}=15.6$. 
minimum value of $13.36 \mathrm{~g}$ for the $37.83 \%$ level of soybean hulls. The nitrogen digested as a percentage of the nitrogen ingested (expressed in \% of ING) displayed a cubic behavior; however, among the diets with different levels of soybean hulls, it fit best to a quadratic equation, with an average value of $72.5 \%$.

The excretion of nitrogen in urine (expressed in $\mathrm{g} / \mathrm{d}$ ) displayed a quadratic behavior $(\mathrm{p}<0.05)$ with the soybean hull substitution, with a minimum value of $0.25 \mathrm{~g}$ for the $34.99 \%$ level. We noted that the highest loss was found with the $100 \%$ soybean hull treatment.

The nutritional demands of ruminants highlight the synchronization between protein and dietary carbohydrates in the rumen to maximize microbial synthesis, thereby reducing nitrogen loss (Owens and Zinn, 1988).

The $\mathrm{N}$ retained (expressed in $\mathrm{g} / \mathrm{d}$ ) was not influenced $(p>0.05)$ by the dietary substitution of corn with soybean hulls. According to Owens and Zinn (1988), the retention of $\mathrm{N}$ is a good estimate of the quantity of $\mathrm{N}$ available for deposition in body tissues, thereby demonstrating that the diets presented adequate nitrogen levels.

The $\mathrm{N}$ retained, as expressed as a percentage of $\mathrm{N}$ ingested (\% of ING), and the $\mathrm{N}$ retained, as expressed as a percentage of $\mathrm{N}$ digested ( $\%$ of $\mathrm{DG}$ ), displayed a quadratic response with the elevation of the level of soybean hulls in the experimental diet; a minimum value for the $68.99 \%$ and $94.30 \%$ levels of soybean hulls was observed.

The nitrogen balance was not influenced $(p>0.05)$ by the level of corn substitution with soybean hulls, presenting an average value of $15.6 \mathrm{~g} / \mathrm{d}$. Thus, the positive nitrogen balance noted in all the treatments indicates that there was no loss of protein or nitrogenous compounds during the experimental period, thereby confirming that the protein fraction in the diets was efficiently absorbed by the animals.

This positive balance indicates that there was a retention of protein in the animals' organisms, thus avoiding weight loss and indicating that the animals' protein and energy demands were most likely satisfied.

\section{CONCLUSIONS}

The substitution of corn with soybean hulls in concentrate up to $1,000 \mathrm{~g} / \mathrm{kg}$ of the diet of lambs does not affect the time spent feeding, ruminating, masticating, or resting. However, increased feeding and ruminating efficiencies and a positive nitrogen balance were observed. Therefore, soybean hulls can substitute for corn up to 1,000 $\mathrm{g} / \mathrm{kg}$ without altering the ingestive behavior or nitrogen balance of the animals.

\section{REFERENCES}

Armentano, L. and M. Pereira. 1997. Measuring the effectiveness of fiber by animal response trials. J. Dairy Sci. 80:1416-1425.

AOAC. 1990. Official methods of analysis. 15th edn. Association of Official Analytical Chemists, Arlington, Virginia.

Bürger, P. J., J. C. Pereira, A. C. Queiroz, J. F. C. Silva, S. C. Valadares Filho, P. R. Cecon, and A. D. P. Casali. 2000. Ingestive behavior in holstein calves fed diets with different concentrate levels. R. Bras. Zootec. 29:236-242.

Carvalho, G. G. P., A. J. V. Pires, R. R. Silva, B. M. A. Carvalho, H. G. O. Silva, and L. M. Carvalho. 2007. Aspectos metodológicos do comportamento ingestivo de ovinos alimentados com capim-elefante amonizado e subprodutos agroindustriais. R. Bras. Zootec. 36:1105-1112.

Carvalho, G. G. P., A. J. V. Pires, R. R. Silva, C. M. Veloso, and H. G. O. Silva. 2008. Comportamento ingestivo de ovinos Santa Inês alimentados com dietas contendo farelo de cacau. R. Bras. Zootec. 37:660-665.

Mertens, D. R. 1997. Creating a system for meeting the fiber requirements of dairy cows. J. Dairy Sci. 80:1463-1481.

National Research Council (NRC). 2001. Nutrient requirements of dairy cattle. 7. ed. Washington, DC: National Academy Press.

National Research Council (NRC). 2006. Nutrient requirements of small ruminants. 1. ed. Washington: National Academy Press, p. 362 .

Owens, F. N. and R. Zinn. 1988. Protein metabolism of ruminant animals. In: The ruminant animal: digestive physiology and nutrition (Ed. C. D. Church). Englewood Cliffs: Prentice Hall. p. $227-268$

Rebouças, G. M. N. 2007. Farelo de vagem de algaroba (Prosopis juliflora) na alimentação de ovinos Santa Inês. 44f. Dissertação (Mestrado em Zootecnia) - Universidade Estadual do Sudoeste da Bahia, Itapetinga.

Ribeiro Junior, J. I. 2001. Análises Estatística no SAEG (Sistema para análises estatísticas). Viçosa, MG: UFV. p. 301.

Silva, D. J. and A. C. Queiroz. 2002. Análises de Alimentos (Métodos químicos e biológicos). 3. ed. Viçosa, MG: Imprensa Universitária. p. 235.

Van Soest, P. J. 1994. Nutritional ecology of the ruminant. 2 ed. Ithaca: Cornell University Press. p. 476.

Van Soest, P. J., J. B. Robertson, and B. A. Lewis. 1991. Symposium: carbohydrate methodology, metabolism, and nutritional implications in dairy cattle. J. Dairy Sci. 74:35833597. 